\title{
TECHNOLOGICAL DEVELOPMENT AND PRODUCTION OF HEALTH SUPPLIES: CHALLENGES FOR THE UNIFIED HEALTH SYSTEM (SUS)
}

\author{
DESENVOLVIMENTO TECNOLÓGICO E PRODUÇÃO DE INSUMOS PARA \\ SAÚDE: DESAFIOS PARA O SISTEMA ÚNICO DE SAÚDE (SUS)
}

\author{
Carlos Eduardo de Andrade Lima da ROCHA ${ }^{1}$; Fabio Kurt SCHNEIDER ${ }^{2}$ \\ 1. Ph.D. in Science - Biomedical Engineering, Master in Science - Biomedical Engineering, Federal University of Technology - Paraná \\ (UTFPR) and Oswaldo Cruz Foundation (FIOCRUZ), Curitiba, PR, Brazil; 2. Ph.D. in Electrical Engineering - University of \\ Washington (USA), Professor at Graduate Program in Biomedical Engineering, Federal University of Technology - Paraná (UTFPR), \\ Curitiba, PR, Brazil. carloseduardoalr@gmail.com
}

\begin{abstract}
This study discusses the Brazilian model of incentives for the domestic development and production of supplies for public health, considering initiatives implemented from 2003 to 2016. This paper was prepared based on a qualitative bibliographic study, considering authors in the fields of health sciences, public health and public policy, reports by the World Health Organization (WHO), the Organization for Economic Cooperation and Development (OECD), Inter-American Development Bank (IDB) and the World Trade Organization (WTO), and official documents available from the Brazilian Federal Government. The paper focuses on the social dimension of health, considering a specific time period in the literature, from 2003 to 2016 and, finally, the new Regulatory Framework for Science, Technology, and Innovation approved in 2016. Various government initiatives were identified in the field of technological development and production to meet the objectives of the SUS according to the literature analysis. Brazil has been substantially increasing investment in Research and Development (R\&D) during the last decade, though it lags European and OECD counterparts. Brazilian investment in R\&D increased from 1.01\% of gross domestic product (GDP) in 2000 to $1.23 \%$ in 2012. Despite being the top performer in Latin America (representing 60\% of total R\&D investment in the region), investment in R\&D in Brazil is approximately half the level of European and OECD countries, which invest on average approximately $2 \%$ and $2.5 \%$ of GDP.
\end{abstract}

KEYWORDS: Health sciences. Public health. Biosciences. Public policies. Innovation

\section{INTRODUCTION}

This study discusses the Brazilian model of incentives for the domestic development and production of supplies for public health, considering actions implemented by the Federal Government from 2003 to 2016.

The Economic-Industrial Healthcare Complex (EIHC) comprises the production of medical equipment and materials, devices and reagents for diagnostics, blood derivatives, biopharmaceuticals etc (BRASIL MINISTÉRIO DA SAÚDE, 2008).

Among these products and supplies, this study highlights the reagents and devices required for diagnostics, a global market valued at USD 25 million and growing at 16\% per year (BRASIL MINISTÉRIO DA SAÚDE, 2008). However, the Brazilian medical devices industry largely depends on the import of strategic supplies to meet the demands of the Unified Health System (Sistema Único de Saúde (SUS)). From this perspective, technological development, production, and incorporation of new biotechnological products into the Brazilian healthcare system is a challenge faced by institutions, researchers, policy makers, and professionals who work in the biomedical area.

It is worth noting that in terms of meeting social demand, the SUS faces severe capacity constraints, leading to long waiting times for specialized medical services, and access to medicines and specialist care can be difficult, particularly in poorer areas (ORGANIZATION FOR ECONOMIC COOPERATION AND DEVELOPMENT (OECD), 2015). In this sense, there is a theoretical alignment with the study by (KICKBUSCH, 2007), whose author states that health in itself became a fundamental force for economic and social drive.

Nevertheless, the studies by Scheffer and Schraiber (2017) and Ocké-Reis (2017) state that SUS funding is a central challenge for Brazil, especially regarding the sustainability of the System. Thus, one should take into consideration that the competition between federal and business entities for markets generates political-budget conflicts among Brazilian states and weakens the public healthcare system of Brazilian regions with poorer economic performance (VIANA ET AL., 2007).

Thus, the intent of this study is not to discuss a specific medical device or technology but 
to show cross-sectional challenges and perspectives in the biomedical area from a broader multidisciplinary viewpoint, particularly with regard to the technological development and production of strategic supplies in healthcare. The objective of this study is to present to researchers, policy makers, healthcare managers and students a branch of biomedical study, using an approach that considers the social implications of technological development in the health field by showing the Brazilian context.

In this context, public policies regarding innovation in healthcare stimulate this area, which can still be explored in the national scope. However, considering that guaranteed healthcare is a constitutional right in Brazil, being a participant in this process is a challenge that, given its complexity, must clearly culminate in multidisciplinary efforts in areas at the edge of scientific knowledge.

To achieve the objective cited above, this article provides a brief characterization of the Brazilian Economic-Industrial Healthcare Complex (EIHC), (Complexo Econômico Industrial da Saúde Brasileiro), a non-exhaustive consideration of the conditions unique to the strategic supplies industry and the challenges connected to the development of these products, and finally a presentation of government actions that result in multidisciplinary efforts in the field of science, technology and innovation (ST\&I), which inevitably touches the biomedical area.

\section{MATERIAL AND METHODS}

This study was prepared based on a qualitative bibliographic study, considering authors in the fields of health economics and public policy who view technological innovation as a pillar of social and economic development, reports by the World Health Organization (WHO), the Organization for Economic Cooperation and Development (OECD), and the World Trade Organization (WTO), and official documents available from the Brazilian Federal Government, in particular the Ministry of Health and the Ministry of Science, Technology, Innovations and Communications.
The literature review considers the 20032016 period, including the first definition of the EIHC by Gadelha et al. (2003), the development of the 2007 Federal Decree that established the Brazilian Biotechnology Development Policy and the publication of the New Regulatory Framework for Science, Technology, and Innovation, Law 13.243/2016, approved by the Brazilian legislature in 2016. The referenced period includes intense academic production regarding the subject of this article.

The study was prepared with contributions from the EIHC, given its relationship with the public policies aimed at increasing activities in health sciences, technology and innovation, particularly in biotechnology. Thus, the EIHC model was analyzed from the perspective of its guidelines and of the multidisciplinary challenges to its implementation, which articulates actions in various areas of knowledge such as biosciences, public health, biomedical engineering, public policy, healthcare management and health innovation.

Finally, without intending to exhaust the subject, several biotechnology developments are discussed and, more precisely, their connection with strategic supplies in public health.

\section{RESULTS AND DISCUSSION}

\section{National Investments in Research and Development (R\&D)}

Brazil now faces the challenge of enhancing economy-wide productivity-driven growth to secure and expand the social achievements of the last decade. Brazil must re-launch its productive transformation and move from an economy based on low value-added in its primary sector industries to an economy based on higher value-added based on knowledge upgrading in all industries (OECD, 2015).

Brazil has been substantially increasing investment in Research and Development (R\&D) during the last decade, though it lags European and OECD counterparts. Brazilian investment in R\&D increased from $1.01 \%$ of gross domestic product (GDP) in 2000 to $1.23 \%$ in 2012 (Figure 1). 


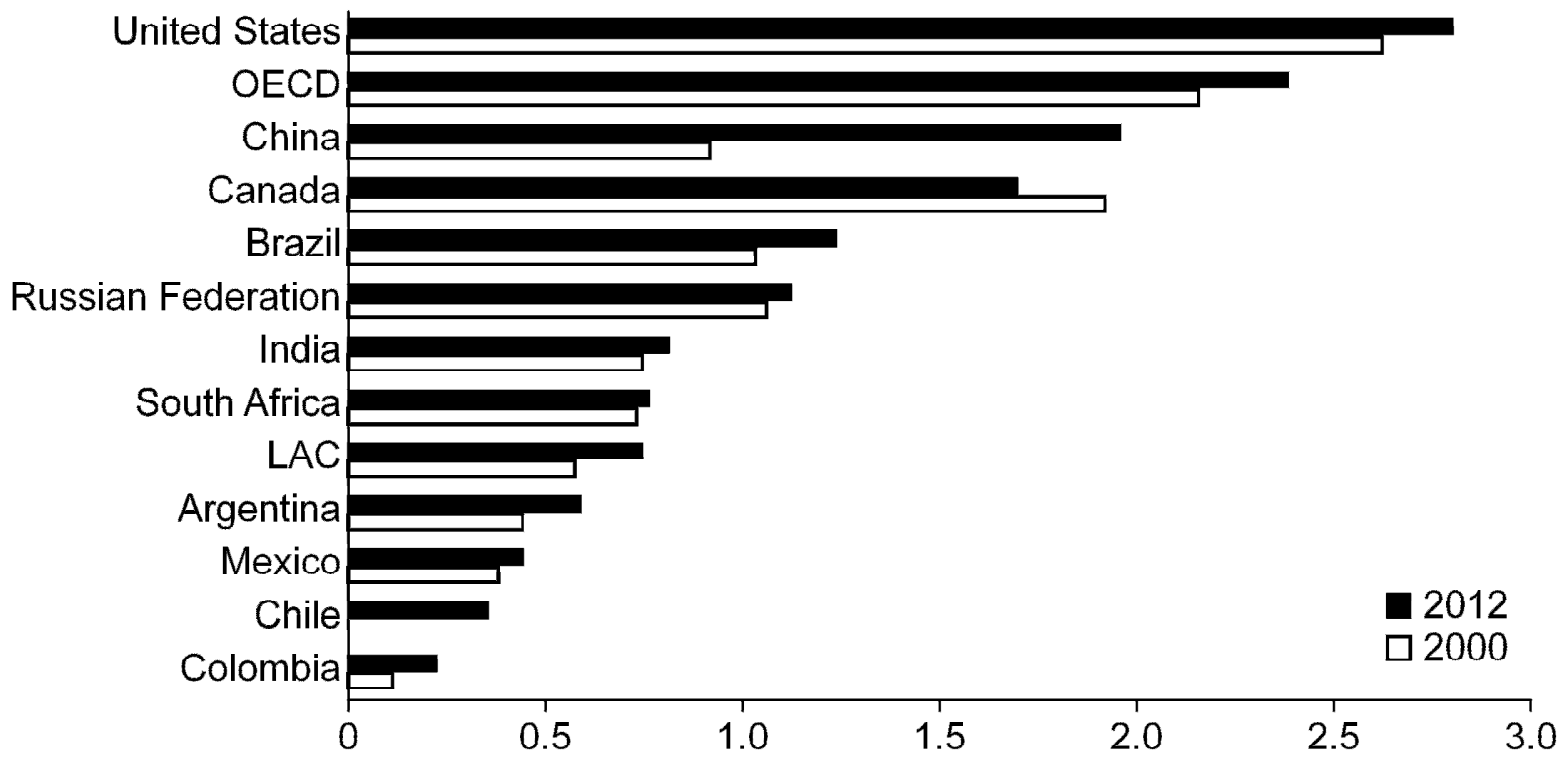

Figure 1. Investments in R\&D as percentage of GDP, OCDE.

Despite being the top performer in Latin America (representing $60 \%$ of total R\&D investment in the region), investment in $R \& D$ in Brazil is approximately half the level of European and OECD countries, which invest on average approximately $2 \%$ and $2.5 \%$ of GDP.

In the OECD, government budget allocations for $\mathrm{R} \& \mathrm{D}$ increased by $2.5 \%$ in 2016 , after a long period of declining R\&D budgets; nevertheless, they remain $8 \%$ below their 2009 level, having fallen by $10 \%$ in the period to 2015 . Related to this, government-financed $\mathrm{R} \& \mathrm{D}$, as recorded by surveys of $R \& D$ performers (rather than amounts budgeted for R\&D by government) declined by $3.2 \%$ between 2010 and 2014 but registered a rise of $0.7 \%$ in 2015 (ORGANIZATION FOR ECONOMIC COOPERATION AND DEVELOPMENT (OECD), 2018).
The most recent data by the Brazilian Ministry of Science, Technology, Innovation and Communication present a percentage of $1.28 \%$ for the national expenditure on research and development ( $R$ \& $D$ ) in relation to the Gross Domestic Product (GDP) in 2015 (BRASIL. MINISTÉRIO DA CIÊNCIA, TECNOLOGIA, INOVAÇÕES E COMUNICAÇÕES, 2017).

According to IPEA (2015), Brazil has increased public research sector inputs and outputs as reflected by R\&D financing of the public sector (universities and research \& technology organizations), supply of $\mathrm{PhDs}$ (formation of advanced human capital), (Figure 2). Substantial increases in public R\&D spending (from $0.52 \%$ to $0.61 \%$ of GDP) occurred over 2003-2010 under President Lula, as the government expanded its science and technology (S\&T) policy to support both academic research and innovation.

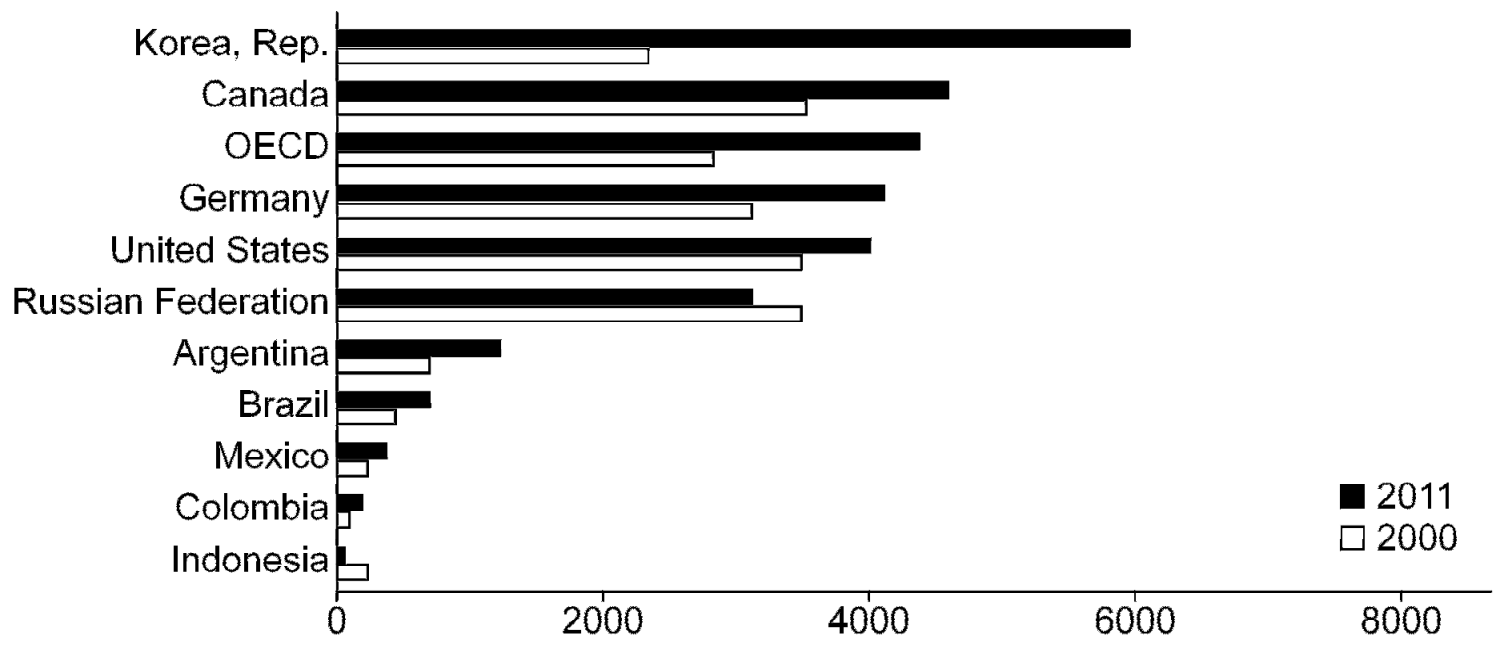

Figure 2. Researchers per million people, OCDE. 
Similarly, it is noted that the objectives defined by the WHO and IDB, described in, respectively, the Statistics Report for 2015 (BRASIL, 2016) and Development in the Americas (BUSSO et al., 2017), emphasize the need for Latin American countries to intensify their efforts in health research and innovation. Nonetheless, it is possible to identify an important increase in Latin American scientific production, as highlighted in Carrasco-Portino et al. (2017)

Adhering to the principles established by the Brazilian Constitution, the Brazilian legislature enacted Law 13.243 on January 11, 2016, establishing incentives for innovation and scientific and technological research in the field of production, with the aim of developing technological training and autonomy and the country's regional and national system of production.

As established in Law n. ${ }^{\circ} 13.243$ (BRASIL, 2016), the Federal Government, the states, the Federal District, the municipalities, the Institutes for Science and Technology (Instituições de Ciência e Tecnologia (ICT)) and their promotion agencies will support and foster R\&D of products, services, and innovative processes in Brazilian companies and Brazilian non-profit organizations.

Implementing the mandates of the 2016 legislation entails clear inter-sectoral challenges. In particular, these challenges involve the training and education of human resources by universities and research institutes as well as placing qualified professionals in the technology industry through contacts with private industry.

With regard to fostering infrastructure, an analysis of Law 13.243/2016 shows that financial support is to be provided largely by the Brazilian public sector, providing the basis for promoting competitiveness in the domestic market. The referred law is consonant and complies with the open innovation approaches and national systems of innovation described and consolidated in the literature by the studies of Chesbrough (2006) and Lundvall et al. (2002).

As highlighted by Gadelha et al. (2013) following the logic of capitalist competition (on an oligopolistic basis), business model in healthcare constitutes a powerful source of asymmetries, private appropriation of the fruits of technical progress, and the exclusion of peoples, regions, and countries. Furthermore, according to the same author, the dependence and underdevelopment of a country have an impact on the healthcare field, restricting the evolution of attention to health and the construction of a universal, equitable, and integral system. However, Gadelha (2006) reinforces the idea of a clear difference in the availability of basic resources between Brazil and countries with a higher level of technological development.

The definition by Gadelha et al. (2003) is adopted, in which the EIHC (Figure 3) comprises the articulation of an interdependent production system that includes the production of medical equipment and materials, devices and reagents for diagnostics, and blood derivatives, among others.

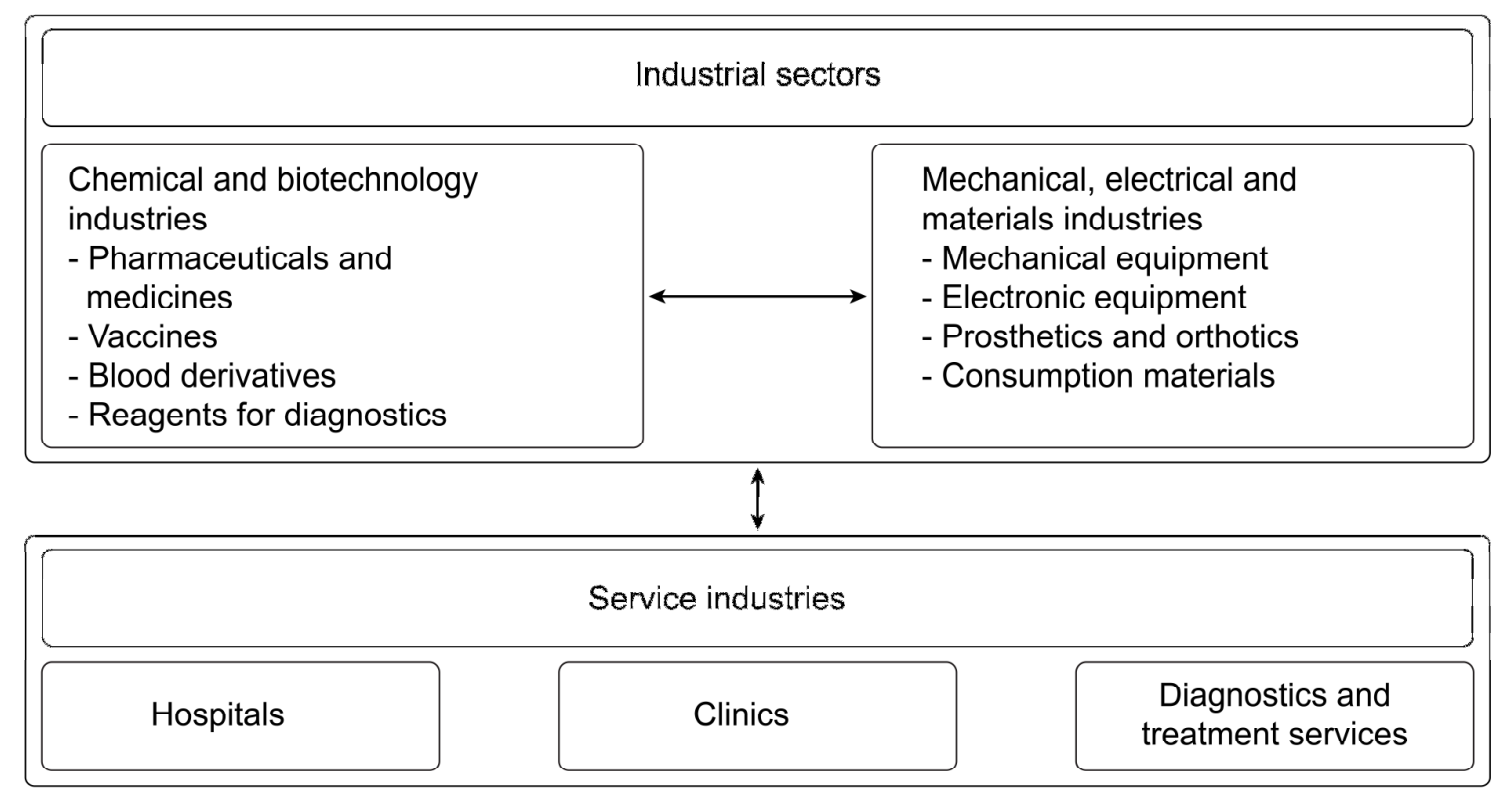

Figure 3. Brazilian industrial healthcare complex - general characterization. 
The general characterization of the EIHC by Gadelha et al. (2003) encompasses the relationship between the industrial sector and the sector that provides services to hospitals, clinics, and diagnostic laboratories, involving an approach to the supply chains for health products.

Based on the analysis of the general characterization complex, the presence of various productive sectors is identified where engineers and scientists are involved in research activities, technological development and industrial production as well as in the service sectors.

Similarly, we can observe that according to Gadelha et al. (2013), the EIHC is uniquely complex, articulating the generation and diffusion of technologies, social institutional dynamics, and the structure of the Brazilian government and its relationship with the private sector. The EIHC involves various sectors and supply chains, science and technology (S\&T) organizations, and government agencies tasked with sanitary regulation, the implementation of industrial, scientific and technological policies, intellectual property, and healthcare, among others.

The combination of these factors with the low level of innovation in the Brazilian pharmaceutical industry, as well as the lack of absorption of technologies and knowledge, exposes a major weakness in guaranteeing the well-being of the population beyond becoming a country dependent on the importation of various supplies and products in healthcare (GADELHA ET AL., 2003).

This situation of external dependence can be estimated by analyzing the results achieved in 2009 by the domestic pharmaceutical market, with sales of approximately USD 17.2 billion and a related commercial deficit of US\$4 billion (ASSOCIAÇÃO BRASILEIRA DAS INDÚSTRIAS DE QUÍMICA FINA BIOTECNOLOGIA E SUAS ESPECIALIDADES (ABIFINA), 2017).

The data from the EIHC trade balance by segment in 2015 demonstrates this vulnerability and indicates concrete threats to collective healthcare management, showing the weakness of the SUS and making explicit the need to associate the increase in national productive capacity (GADELHA; BRAGA, 2016).

The global pharmaceutical market is around USD 1 trillion, and leading pharmaceutical companies invest about $15 \%$ of their net revenue in R\&D activities on average, standing out as one of the most innovative productive sectors in the world, as highlighted in Reis et.al (2016).

In this context, the study by Røttingen et al.,
2013, asserts that the need to align investments in health (R\&D) with public health demands is one of the most pressing global public health challenges.

The challenges of health R\&D mapping are large because there are few standards for research classification and governance and limited capacity to report on R\&D data, especially in low-income countries (TERRY ET AL., 2014).

Based on the latest data available from the Brazilian Ministry of Science, Technology, Innovations and Communications, $R \& D$ funding by the Ministry of Health has grown from USD 141 million in 2003 to USD 425.7 million in 2015 (BRASIL. MINISTÉRIO DA CIÊNCIA, TECNOLOGIA, INOVAÇÕES E COMUNICAÇÕES, 2017).

\section{Healthcare Products and Supplies Industry in Brazil}

The healthcare field can thus be deemed to have a highly unique impact on the economic dynamics of Brazilian society, simultaneously increasing the value of healthcare as a social good and inalienable right (BRASIL MINISTÉRIO DA SAÚDE SECRETARIA-EXECUTIVA, 2009). As recorded in the study by the World Bank (WORLD BANK GROUP, 2017), universal access to services such as water, energy, health, and education have been defined as core principles of the Sustainable Development Goals.

The challenges generated by international competition and by advances in biotechnology produce new conditions for the action of biomedical professionals, including participation in multidisciplinary research projects.

Endemic infectious diseases represent one of the main healthcare problems in developing countries, causing millions of deaths and billions of infections annually and requiring costly ongoing treatment for survivors of these diseases (MABEY et al., 2004) and (TUTTLE, 2016).

According to Gadelha (2009), to perform its duty, the Brazilian government imports equipment and necessary supplies for the construction and maintenance of industrial plants designated to produce supplies for the diagnosis of infectious diseases and provide appropriate treatments.

In this sense, the study by Pérez-Cuevas et al. (2017) reasserts the Brazilian need to improve the access to the Public Health System and, in addition, the importance of providing adequate medication, medical devices and other supplies to the population.

The evolution of the S\&T system was boosted by the institution of distinct financing 
mechanisms and public policies, including the Technological Fund (Fundo Tecnológico (FUNTEC)), the Brazilian National Fund for Scientific and Technological Development (Fundo Nacional de Desenvolvimento Científico e Tecnológico (FNDCT)), the Basic Plans for Scientific and Technological Development (Planos Básicos de Desenvolvimento Científico e Tecnológico (PBDCT)), and, more recently, the Sector Funds (Fundos Setoriais) (VALLE, 2005).

Beginning in the 1990s, the formation of a national system of innovation was evident, marked in general by modest levels of public and private investment, low levels of corporate funding of S\&T and $R \& D$ activities, a restricted degree of interinstitutional interaction, loopholes in legal and regulatory frameworks and inconsistency and discontinuity of actions and public policies, compromising the density and organic nature of the system's institutional environment (VALLE, 2005).

According to the literature review, biotechnology's productive structure and human health biotechnology infrastructure in Brazil are strong and growing; however, they are also concentrated and very dependent on the State. Spatially, they are clustered in the southeastern region of Brazil, especially in a few cities in the state of São Paulo. They are sectorally concentrated, with scientific production of frontier and innovation in few areas of knowledge, such as cardiology, cancer and infectious diseases. Finally, almost all companies, mostly micro and small, rely on public R\&D funding (TORRES-FREIRE ET AL., 2014).

As highlighted by Andrade (2015), in Brazil, from 2004 to 2012, the Department of Science and Technology at the Secretariat of Science, Technology and Strategic Inputs, a division of the Ministry of Health invested USD 45.9 million in $268 \mathrm{R} \& \mathrm{D}$ biotechnology healthcare projects; 141 of them showed progress, especially due to the cofinancing of national and state development agencies.

Considering the importance of public investments in health $\mathrm{R} \& \mathrm{D}$ for economic and social development, according to the Brazilian Development Bank - BNDES (2017), the institution had USD 3.1 billion in its portfolio of health projects in Brazil, of which 52\% were for the health industries and $48 \%$ for health services.

Considering the incentive to health $\mathrm{R} \& \mathrm{D}$ and national production, data from 2017 released by the Brazilian Ministry of Health indicate a total investment of USD 1.9 billion in biological and synthetic products and 7436 qualified jobs within the Economic Industrial Health Complex (BRASIL. MINISTÉRIO DA SAÚDE. GECIS, 2017).

As a result of this study, various initiatives were identified to meet the objective of incorporating new strategic supplies into the SUS. In 2007, the Federal Government established the Biotechnology Development Policy, with emphasis on the area of human health, through decree 6041/2007 (BRASIL, 2017). This decree became the basis of other specific programs focusing on stimulating the generation and control of technologies and national production of various products in the healthcare area.

Investments of approximately USD 2.7 billion were predicted over the next decade. This legislative instrument constitutes a multidisciplinary challenge, as it encompasses various knowledge areas. One example of investment is the Economic Subvention Program for the Innovation of Financing of Studies and Projects (Programa de Subvenção Econômica à Inovação da Financiadora de Estudos e Projetos (FINEP)), of which the share allocated to the biosciences was approximately USD 12.4 million in 2007 and USD 23.1 million in 2008 (BRASIL, 2006).

The Health Innovation Program (Programa Inova Saúde) was an initiative of the Ministry of Science, Technology, Innovations and Communications and FINEP, in cooperation with the Ministry of Health, BNDES and the Brazilian National Council for Scientific and Technological Development $(\mathrm{CNPq})$. This program was created to support R\&D activities in projects of public institutions and private companies operating within the scope of the Economic Industrial Health Complex (EIHC). The program is part of the Innovative Companies Plan, which allocates USD 1.08 billion to the innovation activities of the EIHC. In this strategic program for health R\&D, FINEP included the areas of: biopharmaceuticals, pharmochemicals and medicines, medical devices, health supplies, telehealth and telemedicine, regenerative medicine, blood products, diagnostic reagents and vaccines (FINEP, 2018).

These incentives seek to position the Brazilian industry competitively in the international biotechnology sector, with potential to create new businesses, expand exports, integrate Brazil into the value chain, and stimulate new demand for innovative products and processes (VALLE, 2005).

Thus, FINEP's objectives will be achieved, and the companies in this sector will be able to participate and compete in the international market, collaborating to consolidate the Brazilian biotechnology industry (BRASIL, 2006). 
The results of this study concur with the claims of Valle (2005) that there is a consensus among the authors cited in this article regarding the need for Brazilian government intervention, albeit selective, in the functioning of the economy. According to the study by Baltussen et al. (2017), the relevance of appropriate allocation of resources in the area of health is evident, even in economic restriction scenarios. Thus, according to Tenório et al. (2017), the Brazilian government cannot reduce its support of $S \& T$ activities.

Additionally, from the point of view of Campos et al. (2016) and Campos (2017) the government cannot avoid its duty to guarantee health as a citizen's right. In the same theoretical line, Bahia et al. (2015) and Viana et al. (2017) record in their studies that the government plays a fundamental role in the coordination of public health policies, also considering economic and social development.

Thus, taking into consideration the presented structure, the EIHC and the various authors presented here, the Brazilian government can stimulate the development of new supplies and national expenditure in $\mathrm{R} \& \mathrm{D}$.

The government actions can contribute to fostering innovation in healthcare, competitiveness, and interaction between various actors such as universities, public and private research institutes, companies, hospitals, and industries.

It is observed that the relevance of the government's role through the adoption of sound and effective public policies focused on public health is a central point in the researched literature. This condition is very well defined in the studies by Paim et al. (2011), Noronha (2013) and Hochman (2013).

The advances already achieved in national production of strategic supplies notwithstanding, an important gap between research and production is observed in the creation of solid material conditions aimed at the actors in the Brazilian SUS.

This gap indicates opportunities such as closer cooperation between universities and companies for development in the scope of the EIHC. There is an obvious need for increases in the level of R\&D investments, training of human resources, and, in particular, the processes for the evaluation and incorporation of new technologies into the national market of strategic healthcare supplies.

In the study by Morel et al. (2005), important gaps such as the need for training human resources and ongoing investment in $R \& D$ are highlighted in the production of strategic healthcare supplies, particularly given the magnitude of the problem and the associated challenges that persist despite public and private efforts and incentives for the development of new healthcare products.

Thus, it is clear that quality information about the health system structure is vital for decision making in public health, considering R\&D and the evaluation of public programs (UNDP POLICY IN FOCUS, 2016; WORLD HEALTH ORGANIZATION (WHO), 2014, 2016).

Based on the presented theories, Brazilian Institutes for Science and Technology must make solid, annual investments in health R\&D, with the aim of achieving greater symbiosis with medical devices industries.

The Brazilian government is in a unique position to stimulate the industrial healthcare sector, considering the important efforts made by the Federal Government, which were verified according to the literature analysis. However, to develop or improve production platforms for strategic supplies of national interest, the actors that make up the system must have access to a broad set of resources including professionals who have the ability to bridge other knowledge areas as well as work in collaborative innovation networks.

Based on the data presented, one may conclude that Brazil has a set of laws and public policies that value the social aspect of technological development, including measures that stimulate domestic production over the importation of public health supplies.

The structure and the competitive process of the EIHC, particularly established by Gadelha (2006), constitute a relevant repository of knowledge for the clinical engineering field, healthcare management and technological innovation.

Based on the analysis of the theoretical framework presented in this study, the entrepreneurial role of the Brazilian government is essential to the technological development and production of strategic healthcare supplies.

It is possible to conclude that the actions of the Brazilian Federal Government during the Governments of Presidents Lula and Dilma Rousseff were guided by a policy for articulation of efforts and production of synergies between institutions of various areas of scientific knowledge, both in the public and private sectors.

Another point worth highlighting in the findings of this study is the alignment of government actions with the guidelines outlined in the official WHO (2016), IDB (BUSSO ET AL., 2017) and OECD $(2014,2015)$ reports, especially 
when we analyze the central objectives of the New Regulatory Framework for Science, Technology, and Innovation, Law 13.243/2016, approved by the Brazilian legislature in 2016.

Another fundamental aspect observed speaks to the demand for qualified human resources in areas at the edge of human knowledge (i.e., genomics, proteomics, nanobiotechnology, and bioinformatics associated with the analysis of large data sets, among others). Opportunities are also noted for the insertion of professionals who work in the biomedical area prospecting for international patents, particularly for models and methods of protein engineering, molecular markers, and supplies for use in diagnostic devices, in view of developing and incorporating new products into the SUS.

Despite the Brazilian government's efforts, the trade balance for pharmaceutical products continues to run a sizable deficit, on the order of US\$ 5.8 billion in 2015, according to WTO-World Trade Organization (2017).

Thus, given that the intent of this study was not to provide an exhaustive account of the EIHC and the multidisciplinary challenges faced by biomedical research, this article opens a path for future studies, including an analysis of the impact of public policies in the biomedical area.

By analyzing the data obtained by the research carried out, there is a clear need for the maintenance of state investments in the health area, in order to preserve the social rights provided to Brazilians.

Finally, even considering fragilities and gaps that still exist, it was possible to observe the constitution of public policies and legislation aimed at strengthening national technological development and the production of strategic inputs for the SUS.

\section{ACKNOWLEDGEMENTS}

The authors acknowledge the Graduate Program in Biomedical Engineering - Electrical and Industrial Information Technology of the Federal University of Technology - Paraná (UTFPR), the Science and Technology National Institute for Public Healthcare Diagnostics (INCT-CNPq) and the Oswaldo Cruz Foundation (FIOCRUZ) for their financial support and for their support in conducting this study.

RESUMO: Este artigo pretende discutir o modelo brasileiro de incentivos para o desenvolvimento interno e produção de insumos para saúde pública, considerando ações governamentais implementadas no período de 2003 a 2016. O artigo foi elaborado com base em estudo bibliográfico qualitativo, considerando autores nas áreas de economia da saúde, saúde pública e políticas públicas, relatórios da Organização Mundial de Saúde (OMS), Organização para a Cooperação e Desenvolvimento Econômico (OCDE), Banco Interamericano de Desenvolvimento (IDB) e Organização Mundial do Comércio (OMC), bem como documentos oficiais disponíveis do Governo Federal Brasileiro. O estudo aborda a dimensão social da saúde, considerando um período de tempo específico na literatura, de 2003 a 2016 e, finalmente, o novo Marco Legal da Ciência, Tecnologia e Inovação aprovado em 2016. Diversas iniciativas governamentais para atingir os objetivos do SUS foram identificadas, de acordo com a análise da literatura. O Brasil tem aumentado substancialmente o investimento em Pesquisa e Desenvolvimento (P \& D) durante a última década, embora fique atrás de países europeus e da OCDE. O investimento brasileiro em P \& D aumentou de 1,01\% do produto interno bruto (PIB) em 2000 para $1,23 \%$ em 2012. Apesar de ter o melhor desempenho na América Latina (representando $60 \%$ do investimento total em P \& D na região), o investimento em $\mathrm{P} \& \mathrm{D}$ no Brasil é aproximadamente metade do nível dos países europeus e da OCDE, que investem em média aproximadamente $2 \%$ e $2,5 \%$ do PIB.

PALAVRAS-CHAVE: Ciências da saúde. Saúde pública. Biociências. Políticas públicas. Inovação.

\section{REFERENCES}

ANDRADE, P. A. Avaliação da Política Nacional de Ciência, Tecnologia e Inovação em Saúde: contribuições para a pesquisa \& desenvolvimento em biotecnologia em saúde (2004-2014), tese de doutorado. Departamento de Serviço Social, Universidade de Brasília. Brasília, DF, 2015.

ASSOCIAÇÃO BRASILEIRA DAS INDÚSTRIAS DE QUÍMICA FINA BIOTECNOLOGIA E SUAS ESPECIALIDADES (ABIFINA). Available in: <http://www.abifina.org.br/default.asp >. Accessed 6 May 2017. 
BAHIA, L.; COSTA, L. S.; GADELHA, C. A.; VARGAS, M. A. Compras governamentais: as mãos visíveis do Estado para a inovação [Government procurement: the visible hand of the state for innovation]. Saúde, Desenvolvimento e Inovação. Rio de Janeiro: CEPESC-IMS/UERJ-FIOCRUZ, 2015. 349 p.

BALTUSSEN, R.; MITTON, C.; DANIS, M., WILLIAMS, I.; GOLD, M. Global developments in priority setting in health. Int J Health Policy Manag, v. 6, n. 3, p. 127-128, 2017.

https://doi.org/10.15171/ijhpm.2017.10

\section{BANCO NACIONAL DO DESENVOLVIMENTO (BNDES). O apoio do BNDES às Entidades}

Filantrópicas de Saúde. Departamento do Complexo Industrial e de Serviços de Saúde. Câmara dos Deputados. Comissão Especial - PL 7606/2017. Available in: <http://www2.camara.leg.br/atividadelegislativa/comissoes/comissoes-temporarias/especiais/55a-legislatura/pl-7606-17-linhas-de-credito-as-santascasas/documentos/audiencias-publicas/joao-paulo-pieroni-04-07-2017-bndes>. Accessed in: Dec 2017

BRASIL. Ministério do desenvolvimento, indústria e comércio exterior, fórum de competitividade de biotecnologia. Estratégia nacional de biotecnologia: política de desenvolvimento da bioindústria. Brasília: Centro de Gestão e Estudos Estratégicos - CGEE, 2006.

BRASIL. Lei no 13.243 , de 11 de janeiro de 2016. Dispõe sobre estímulos ao desenvolvimento científico, à pesquisa, à capacitação científica e tecnológica e à inovação. Brasília: Diário Oficial da União, 2016.

BRASIL. Decreto. n. 6.041. Institui a política de desenvolvimento da biotecnologia, cria o comitê nacional de biotecnologia e dá outras providências. Available in: <http://www.planalto.gov.br/ccivil_03/_Ato20072010/2007/Decreto/D6041.htm>. Accessed in: Aug 2017.

BRASIL. MINISTÉRIO DA CIÊNCIA, TECNOLOGIA, INOVAÇÕES E COMUNICAÇÕES. Indicadores Nacionais de Ciência, Tecnologia e Inovação - 2017. Available in: $<$ http:// www.mctic.gov.br/mctic/opencms/indicadores/indicadores_cti.html >. Accessed in: May 2018

BRASIL. MINISTÉRIO DA SAÚDE. Tecnologia e inovação em saúde. Available in: $<$ http://bvsms.saude.gov.br/bvs/publicacoes>. Accessed in: Aug 2017.

BRASIL. MINISTÉRIO DA SAÚDE. GECIS. Investimentos no Complexo Industrial da Saúde. Grupo Executivo do Complexo Industrial da Saúde, GECIS. 2017. Available in:

<http://portalarquivos2.saude.gov.br/images/pdf/2017/dezembro/14/13.12.2017.GCIS.pdf >. Accessed in: May 2018.

BRASIL. MINISTÉRIO DA SAÚDE. SECRETARIA-EXECUTIVA. Mais gestão é mais saúde : governança para resultados no ministério da saúde. Brasília: Ministério da Saúde, 2009.

BUSSO, M.; CRISTIA, J.; HINCAPIE, D.; MESSINA, J.; RIPANI, L. Learning better: public policy for skills development. Technical report, Inter-American Development Bank, 2017.

https://doi.org/10.18235/0000799

CAMPOS, G. W. D. S.; BEDRIKOW, R.; SANTOS, J. A.; TERRA, L. S. V.; FERNANDES, J. A.; BORGES, F. T. Direito à saúde: o sistema único de saúde (SUS) está em risco? Interface Comunicação, Saúde, Educ, v. 20, p. 261-266, 2016. https://doi.org/10.1590/1807-57622015.0409

CAMPOS, G. W. S. Entrevista: desigualdade é o conceito-chave para a discussão da saúde no contexto internacional. Cien Saude Colet, v. 22, n. 7, p. 2315-2319, 2017. https://doi.org/10.1590/1413-

81232017227.08752017

CARRASCO-PORTINO, M.; ZAPATA, L. G.; GARCIA, L. P.; BERMUDEZ-TAMAYO, C.; ALVAREZDARDET, C. Evidence-based public health in Gaceta Sanitaria: a nod to Latin America. Gac Sanit, v. 31, n. 1, p. 1, 2017. 
CHESBROUGH, H. W. Open innovation: the new imperative for creating and profiting from technology. Boston, MA: Harvard Business School Press, 2006.

GADELHA, C. A.; QUENTAL, C.; FIALHO BDE, C. Health and innovation: a systemic approach in health industries. Cad Saude Publica, v. 19, n. 1, p. 47-59, 2003. https://doi.org/10.1590/S0102311X2003000100006

GADELHA, C. A. G. Desenvolvimento, complexo industrial da saúde e política industrial. Rev Saude Publica, v. 40, p. 11-23, 2006. https://doi.org/10.1590/S0034-89102006000400003

GADELHA, C. A. G. Relatório. Pesquisa perspectivas do investimento em ciência, UNICAMP e UFRJ, financiada pelo BNDES. Available in:

$<$ http://www.bndes.gov.br/SiteBNDES/export/sites/default/bndes_pt/Galerias/Arquivos/empresa/pesquisa/pib/p ib_ciencia.pdf $>$. Accessed in: Aug 2017.

GADELHA, C. A. G.; BRAGA, P. S. D. C. Health and innovation: economic dynamics and Welfare State in Brazil. Cad Saude Publica, v. 32, n. 2, p. e00150115, 2016. https://doi.org/10.1590/0102-311X00150115

GADELHA, C. A. G.; COSTA, L. S.; DE VARGE MALDONADO, J. M. S.; BARBOSA, P. R.; VARGAS, M. S. The health care economic-industrial complex: concepts and general characteristics. Health, v. 5, n. 10, p. 1607-1621, 2013. https://doi.org/10.4236/health.2013.510217

FINANCIADORA DE ESTUDOS E PROJETOS (FINEP). Programa Inova Saúde. Available in: $<$ http://www.finep.gov.br/apoio-e-financiamento-externa/programas-e-linhas/programas-inova/inova-saude $>$. Accessed in: May 2018.

HOCHMAN, G. Saudades do futuro ou um sistema de saúde em tempos democráticos. Cad Saude Publica, v. 29, n. 10, p. 1949-1949, 2013. https://doi.org/10.1590/0102-311XCO071013

INSTITUTO DE PESQUISA ECONÔMICA APLICADA (IPEA). Conditions for innovation in Brazil: a review of key issues and policy challenges. World Bank in collaboration with Organization for Economic Cooperation and Development (OECD), 2015. Available in: <http://

www.innovationpolicyplatform.org/system/files/CONDITIONS\%20FOR\%20INNOVATION\%20IN\%20BRA ZIL_Background\%20Paper_Website_2.pdf>. Accessed in: May 2018

KICKBUSCH, I. Innovation in health policy: responding to the health society. Gac Sanit, v. 21, n. 4, p. 338342, 2007. https://doi.org/10.1157/13108509

LUNDVALL, B. Å.; JOHNSON, B.; ANDERSEN, E. S.; DALUM, B. National systems of production, innovation and competence building. Res Policy, v. 31, n. 2, p. 213-231, 2002. https://doi.org/10.1016/S00487333(01)00137-8

MABEY, D.; PEELING, R. W.; USTIANOWSKI, A.; PERKINS, M. D. Diagnostics for the developing world. Nat Rev Microbiol, v. 2, n. 3, p. 231-240, 2004. https://doi.org/10.1038/nrmicro841

MOREL, C. M. et al. Health innovation networks to help developing countries address neglected diseases. Science, v. 309, n. 5733, p. 401-404, 2005. https://doi.org/10.1126/science.1115538

NORONHA, J. C. D. Cobertura universal de saúde: como misturar conceitos, confundir objetivos, abandonar princípios. Cad Saude Publica, v. 29, n. 5, p. 847-849, 2013. https://doi.org/10.1590/S0102-

311X2013000500003

OCKÉ-REIS, C. O. Política social, desenvolvimento e cidadania: a história também anda para trás. In: RODRUGUES, P. H. da; SANTOS, I. S. (Ed.). Políticas e riscos sociais no Brasil e na Europa: convergências e divergências. Rio de Janeiro: Cebes, Hucitec Editora, 2017. p. 205-208. 
ORGANIZATION FOR ECONOMIC COOPERATION AND DEVELOPMENT (OECD). Industry, science, technology and industry outlook. Paris: Organization for Economic Cooperation and Development, 2014.

ORGANIZATION FOR ECONOMIC COOPERATION AND DEVELOPMENT (OECD). Economic surveys: Brazil. Paris: OECD Publishing, 2015.

ORGANIZATION FOR ECONOMIC COOPERATION AND DEVELOPMENT (OECD). Main Science and Technology Indicators Database. Available in: <http://www.oecd.org/sti/msti.htm>. Accessed in: May 2018

PAIM, J.; TRAVASSOS, C.; ALMEIDA, C.; BAHIA, L.; MACINKO, J. The Brazilian health system: history, advances, and challenges. Lancet, v. 377, n. 9779, p. 1778-1797, 2011. https://doi.org/10.1016/S01406736(11)60054-8

PEREZ-CUEVAS, R. et al. Understanding public perception of the need for major change in Latin American healthcare systems. Health Policy Plan, v. 32, n. 6, p. 816-824, 2017. https://doi.org/10.1093/heapol/czx020

REIS, C.; BARBOSA, L. M. L. H.; PIMENTEL, V. P. O desafio do envelhecimento populacional na perspectiva sistêmica da saúde. BNDES Setorial, n. 44, p. 87-124, 2016.

RØTTINGEN, J-E.; REGMI, S.; EIDE, M. et al. Mapping of available health research and development data: what's there, what's missing and what role is there for a global observatory. Lancet, v. 382, p. 1286-1307, 2013. https://doi.org/10.1016/S0140-6736(13)61046-6

SCHEFFER, M.; SCHRAIBER, L. B. Interface, vinte anos: a saúde coletiva em tempos difíceis. Interface Comunicação, Saúde, Educ, v. 21, p. 487-491, 2017. https://doi.org/10.1590/1807-57622017.0288

TENÓRIO, M.; MELLO, G. A.; VIANA, A. L. D. Políticas de fomento à ciência, tecnologia e inovação em saúde no Brasil e o lugar da pesquisa clínica. Cien Saude Colet, v. 22, p. 1441-1454, 2017. https://doi.org/10.1590/1413-81232017225.33342016

TERRY, R. F.; SALM JR, J. F.; NANNEI, C.; DYE, C. Creating a global observatory for health R\&D. Science, v. 345, n. 6202, p. 1302-134, 2014. https://doi.org/10.1126/science.1258737

TORRES-FREIRE, C.; GOLGHER, D.; CALLIL, V. Biotecnologia em saúde humana no Brasil: produção científica e pesquisa e desenvolvimento. Novos estud. - CEBRAP, São Paulo , n. 98, p. 69-93, 2014.

TUTTLE, J. Drug development for neglected tropical diseases: DNDi and the product development partnership (PDP) model. Durham, NC: Department of global health, Duke University, 2016.

UNDP, Policy in Focus, Health policy in emerging economies: innovations and challenges. The international policy centre for inclusive growth, in collaboration with fundação oswaldo cruz (Fiocruz), United Nations Development Programme, 2016. Available in: <http://www.ipc-

undp.org/pub/eng/PIF35_Health_policy_in_emerging_economies_innovations_and_challenges.pdf $>$.

VALLE, M. G. O Sistema nacional de inovação em biotecnologia: possíveis cenários, tese de doutorado. Departamento de política científica e tecnológica-unicamp. Campinas, São Paulo, 2005.

VIANA, A. L.; DA SILVA, H. P.; YI, I. Universalizing health care in Brazil: opportunities and challenges. In: Yi I (Ed.). Towards universal health care in emerging economies. Social policy in a development context. London: Palgrave Macmillan, 2017. p. 181-211. https://doi.org/10.1057/978-1-137-53377-7_7

VIANA, A. L. D. et al. Universal health systems and territory: challenges for a regional policy in the Brazilian Legal Amazon. Cad Saude Publica, v. 23, n. 2, p. S117-S131, 2007. https://doi.org/10.1590/S0102311 X2007001400002 
WORLD BANK GROUP. Global economic prospects, january 2017: weak investment in uncertain times. Washington, DC: World Bank, 2017.

WORLD HEALTH ORGANIZATION (WHO). World health statistics 2016: monitoring health for the SDGs, sustainable development goals. Available in:

<http://www.who.int/gho/publications/world_health_statistics/2016/EN_WHS2016_TOC.pdf>.

WORLD HEALTH ORGANIZATION (WHO). Health statistics and information systems. Available in: $<$ http://www.who.int/healthinfo/en/>. Accessed in: Aug 2017

WORLD TRADE ORGANIZATION (WTO). Statistics database. Merchandise trade by commodity. Available in: <http://stat.wto.org>. Accessed in: Nov 2017 